\title{
The second Karabakh war as a war of new generation
}

\author{
Khayal Iskandarov ${ }^{1}$ A; Piotr Gawliczek ${ }^{2}$ B \\ A War College of the Armed Forces, Republic of Azerbaijan \\ B University of Warmia and Mazury, Poland
}

Received: April 10, 2021 | Revised: April 21, 2021 | Accepted: April 30, 2021

DOI: $10.33445 /$ sds.2021.11.2.9

\begin{abstract}
The paper examines the views and ideas of various military experts and researchers on the war, broke out between Armenia and Azerbaijan in late September, 2020. The Second Karabakh has been presented as a sample of the new generation warfare. The authors endeavored to substantiate the importance of the Second Karabakh War in the world's military history by a variety of conclusive facts. Having considered the uniqueness of this war, a number of important lessons have been introduced in order to understand the nature of future wars.
\end{abstract}

Key words: second Karabakh War, "Operation Iron Fist", Patriotic War, 44-day war, NagornoKarabakh.

\section{$\underline{\text { Introduction }}$}

The counter-offensive operation launched by the Armed Forces of the Republic of Azerbaijan on September 27, 2020 is the largest military campaign in the South Caucasus region since the 1990s. Neither Armenia nor its foreign supporters have imagined that the processes would have happened in this way. The Second Karabakh War attracted the attention of many foreign researchers and experts, both in terms of the modernity of the technology used and the specificity of combat tactics. Even some military institutions and organizations studied various aspects of this war and decided to teach its results in higher military schools. The extraordinary and secret meeting of NATO in Berlin to analyze the experience of the 44-day war, and the participation of high-ranking Pentagon officials online through secure Internet channels (Piriyev, Heydər), proves this once again. According to Michael Kofman, a U.S. military expert, the United States has studied many conflicts, such as the 1973 Arab-Israeli war and identified areas for future investment in the military. As a result, it deeply analyzes the Russian-Ukrainian conflict and the ArmenianAzerbaijani war (Kofman, Michael, December
21, 2020). Gustav Gressel states that, Europe must learn a military lesson from this war. The researcher claims that the armies of most European countries (except France and Germany) may find themselves in the miserable situation in which the Armenian army was mired (Gustav Gressel).

According to Paul Iddon, it may take some years of retrospective analysis to conclusively determine that Azerbaijan may have been among the first to demonstrate how in the 21st century, small nations can increasingly deploy such advanced weapons systems to compensate for their size and decisively prevail against equal or even more powerful opponents (Paul Iddon). Even though a number of researchers, political and military experts touched upon various aspects of the Second Karabakh War, no definitive scientific study has been conducted yet. The purpose of this paper is to analyze the views of various researchers on the Second Karabakh War and highlight the significance of this war for taking military lessons. The work is mainly theoretical and uses methods of analysis, synthesis, induction and deduction.

\footnotetext{
${ }^{1}$ Corresponding author: e-mail: xayal1333@gmail.com, ORCID: 0000-0001-8975-6530

2 Assoc. Prof., PhD, e-mail: pgawliczek@gmail.com, ORCID: 0000-0002-0462-1168
} 


\section{Results and discussion}

The Armenian-Azerbaijani "Nagorno-Karabakh conflict" has entered the history of the twentieth century as one of the most tragic conflicts, the consequences of which have seriously affected the fate of millions of people. Until the peace agreement of November 10,2020, the conflict had been accentuated as one of the most protracted conflicts. For twenty-seven years, Yerevan had eschewed negotiations and international community simply observed and OSCE Minsk Group co-chairs made formal statements. For the last 5-6 years the Nagorno-Karabakh conflict had been at the focus of attention with sporadic shootings. August 2014, April 2016, July 2020 were more conspicuous months with regard to the confrontation between the parties. That was the reality of the "Nagorno-Karabakh conflict". Everything was evident, Armenia had occupied Azerbaijan's territory and Baku had tolerated for approximately thirty years with an expectation of peaceful settlement of the conflict. Azerbaijan had always expressed a will for peaceful settlement of the conflict. It should be particularly mentioned that, Armenia had other territorial claims in Azerbaijan in order to extend its so-called "security belt". There were intelligence reports that Armenia had been planning an offensive operation against Azerbaijan with the purpose of seizing other lands. Armenian policy of transferring YPG/PKK terrorists who received training in Iraq and Syria to Nagorno-Karabakh region is a proof of our argument. Pashinyan's government had been preparing for war, while the world community expected them to prepare their nation for peace. Finally, on September 27, Armenian Armed Forces initiated offensive operations along the entire frontline. However, Azerbaijan Armed Forces launched counteroffensive, which ushered in a new security environment in the region. Azerbaijan's resolute counter-offensive operation against Armenia reverberated around the globe. Thus, Azerbaijan Armed Forces smashed the first echelon of Armenian Army and broke down the so-called "impregnable defense line". Armenian government did not expect it; therefore,
Azerbaijan's successful combat operations shattered their reputation among Armenian community. The 44-day Second Karabakh War, enshrined in the military history of Azerbaijan as a Patriotic War or "Operation Iron Fist" is touted as the sample of modern war with its unique features. In this paragraph we will try to elaborate on these features.

On the third day of the Second Karabakh War, the commander of the US Marine Corps, General David Berger, said that the strategy implemented in Nagorno-Karabakh was taken into account in various training scenarios a year ago. Commenting on the opinion of some researchers that "tanks are no longer needed", the general said: "The Marine Corps doesn't find tanks to be obsolete, but in 2019 it decided to stop investing in the heavy armor after a series of wargames concluded that they were at a strategic disadvantage against precision strikes like the one supposedly carried out in the fight for Nagorno-Karabakh" (Morgan, Jared).

In fact, although not directly, General Berger acknowledged that tanks had lost their importance, emphasizing their vulnerability to UAVs. However, along with the soldiers, the tank is still an extremely important tool in capturing and consolidating the positions, which is considered a fundamental condition of war. In short, a place where a soldier does not put his boots is not considered captured. Tanks play an important role in their protection. Therefore, it is unprofessional to say that "tanks have lost their relevance and must be dismantled". As a result, the Second Karabakh War showed that against the background of the growing demand for UAVs, other weapons (equipment) and highly trained ground troops play an exceptional role in destroying the enemy in modern wars.

Along with the new technological capabilities, the military tactics applied by the Armed Forces of the Republic of Azerbaijan also attracted the attention of military experts and researchers due to their uniqueness. The Azerbaijani Army's attack was based on detailed reconnaissance, artillery and UAV strikes. Although this tactic was similar to the tactics used by the Turkish Armed Forces in 
2018 in the Syrian city of Afrin and Idlib province, it differed significantly in scale, form of relief and military potential of the enemy. Because the war in Nagorno-Karabakh was fought on a front of about $200 \mathrm{~km}$, the relief was extremely complicated. In addition, the strength of terrorists in Syria was much weaker than the military strength of the Armenian army. Georgian researcher Mariam Jintcharadze notes that "the six-week war proved two facts: 1) the effectiveness of Turkey-Azerbaijan cooperation and 2) the strength of the Azerbaijani Army" (Jintcharadze, Mariami).

The vast majority of the military experts and researchers observing the war stressed that the fate of the war was determined in favor of Azerbaijan in the second half of October. After Pashinyan's "famous" speech on October 21 (the Prime Minister of Armenia Nikol Pashinyan put forward a proposal consisting of six steps: 1) create volunteer groups (minimum 30 people); 2) choose a commander from them; 3 ) apply to the military commissariat where the commander lives; 4) undergo training in one of the military units; 5) go to the front to defend the "homeland"; 6) win a victory), the Armenian government hoped that a group of volunteers would be formed and join the army for fighting. Undoubtedly, this unprofessional approach did not justify itself and Armenian citizens not only avoided fighting voluntarily, but even began to eschew military service. On October 24, three days after Pashinyan's address to the nation, military expert Michael Kofman described the situation in the war as follows: "Armenian armed forces in NagornoKarabakh are facing a military catastrophe. Azerbaijani drone and artillery strikes gradually weakened them and forced them to retreat regularly. Unlike the first days of the war, the Azerbaijan Armed Forces have been advancing faster in the last two weeks. Jabrayil, Hadrut and Fizuli are under the control of Azerbaijan. The Azerbaijani Army is moving west to the Hakari River and at the same time to the North. The Lachin corridor is within the firing range of the Azerbaijani Army artillery. It is expected that the Azerbaijani Army will capture this critical supply route in a few days or at least restrict the movement there. The war is not over, but it is clear that Armenia has no way to reverse such gains or reconstitute its substantial losses. Consequently, Baku can already claim a significant political victory based on battlefield performance and territory brought back under its control" (Kofman, Michael, October 24, 2020). About the same time, Jack Watling, research fellow at the Royal United Services Institute, highlighted Azerbaijan's superiority on the battlefield: "The Armenians have been caught off guard. Because one side is deploying modern weaponry and the other is using weaponry from the 1970s and 1980s" (Foy, Henry) (Foy, Henry). Ridvan Ucrosta, a Polish researcher who compared the UAVs of both sides, said: "Compared to the Harop, Orbiter-3, Orbiter-2, SkyStriker, Hermes-900, Thunder-B, Orbiter-2M, Aerostar, Hermes-450 and Heron-1 used by Azerbaijan on the battlefield, Armenian Krunk or Crane drones are three times less effective" (Urcosta, Ridvan).

Analyzing the military processes in late October and early November, Dmitry Kuznets said: "There was little hope that the Armenian military units in Nagorno-Karabakh would survive the defeat in such a situation. It is obvious that the resources in Nagorno-Karabakh and even in Armenia, have been exhausted. So far, all counter-offensive operations carried out by the Armenian Army have resulted in heavy losses, which led to the rapid advance of the Azerbaijani side to Shusha" (Kuznets, Dmitry).

Consequently, the analysis of the researchers' views on the Second Karabakh War shows that Azerbaijan demonstrated apparent elements of new generation warfare.

\section{Lessons learned from the Second Karabakh War}

The 44-day Patriotic War, enshrined in the military history of Azerbaijan, proved the will of the political leadership of the Republic of Azerbaijan and the military strength of the Armed Forces in the international arena. It is true that the Armenian Army was not weak, it was simply not able to satisfy the claims of the political and military leadership. Our analysis proves that the Azerbaijani Armed Forces did not defeat a weak army presented by some experts, but an army that had been preparing for this war for years and had received sufficient support from foreign backers. 
Thus, the Patriotic War, which is distinguished for its many specific features, will be the subject of many studies in the foreseeable future or even in the long run, attracting the attention of various researchers and experts in security and military sciences. Having analyzed the uniqueness of the Second Karabakh war, the following very important lessons can be taken to understand the nature of future wars:

1. The traditional ground forces are in trouble without adequate sensors, electronic warfare cover and counter-drone weaponry. According to Can Kasapoglu, the Second Karabakh War proved the vulnerability of traditional ground forces (armored and mechanized) to advanced drone weaponry (Kasapoglu, Can). In total, during the 44day war, about 1,500 enemy air defense and artillery systems, armored and other vehicles were destroyed (Piriyev, Heydər) where drone activity was of particular importance. Michael Kofman states that "the Second Karabakh War showed that the Soviet missile defense systems used by the Armenian army were unsuitable for combating modern UAVs" (Kofman, Michael, October 24, 2020). The combined use of UAVs to identify and strike them, as well as the mass use of drones were key elements in distinguishing this war.

2. In modern wars, integration of land-based fire-support and drones is very important. In many of the clashes, including the night battles of the Second Karabakh War, the Azerbaijani Army's artillery and missile systems operated in coordination with drones (Kasapoglu, Can). As a result, we witnessed a growing trend of combining artillery fire with UAVs in modern wars. This use of UAVs is a key feature of modern warfare. Mike Eckel claims that "before the outbreak of the Second Karabakh War, the Armed Forces of the Republic of Azerbaijan had about 200 UAV models in its inventory" (Eckel, Mike). According to the Stockholm International Peace Research Institute, in 2010-2014, Azerbaijan ranked fourth in the world in terms of UAV imports with 7.8\% (Arzu Abbasova). Emphasizing the importance of the Turkish-made Bayraktar (TB2) on the battlefield, Rob Lee, a former US Marine Corps officer and a researcher in martial arts at King's College London said: "We have not seen such achievements in the last 20-25 years that Azerbaijan obtained on the battlefield" (Piriyev, Heydor). At the same time, high-precision artillery weapons (Polonez, Gasirga, LORA and Spike) fully provided the firepower of the Azerbaijani Army in the war. The targets considered inadequate for drone strikes were destroyed by artillery fire due to their coordinates provided by the UAVs, thus integrating fire support with drone activities. According to Vasily Kashin, a researcher at the Middle East Institute of the Russian National Academy of Sciences, Azerbaijan's spending on armaments was more logical and its planning was more careful. The funds had not been wasted, the latest military developments had been taken into account and the experience of the war in the Middle East had been studied. They had prepared for this war in an exemplary manner and this preparation covered not only the military aspects, but also the political, economic and propaganda issues (Aksenov, Pavel). In fact, Armenia had been preparing for this war for decades. Along with the development of strong fortifications, according to the Stockholm International Peace Research Institute (SIPRI), Armenia's imports of weapons, equipment and military supplies in 2014-2019 was 3.5 times higher than it was in 2009-2014 (Aksenov, Pavel).

3. Intra-war deterrence gain importance. It should be taken into account that the Armenian side, overwhelmed by the successful counteroffensive operation of the Azerbaijani Army, targeted the densely populated cities and settlements of Azerbaijan, as well as the national infrastructure with ballistic missiles. This behavior, which is legally considered a war crime, necessitates the concept of "intra-war deterrence". The concept of "intra-war deterrence" implies the control of various escalations during the ongoing war. Unlike traditional deterrence strategies, the concept of "intra-war deterrence" functions only within an ongoing war (Kasapoglu, Can). Shocked by Azerbaijan's technological superiority on the battlefield, Armenia, as we noted, fired at the Azerbaijani settlements with ballistic missiles and rocket launchers (MLRS). "Iskandar" operationaltactical missiles in the armament of the Armenian army made the situation even more dangerous. The bombing of the city of Ganja by rocket and 
artillery strikes a day after the ceasefire agreement reached in Moscow on October 10, 2020 demonstrated the seriousness of the threat. According to Peter Tese, a US political scientist and professor at the University of Wisconsin, Armenia's move was tantamount to the 1939 bombing of Warsaw by Hitler's army. Professor warned the EU countries, the Parliamentary Assembly of the Council of Europe, the Council of Europe and the US State Department about the direct effects and geopolitical consequences of the terrorist acts carried out by the leadership of Yerevan: "It is an even stronger reason for the liberation of every inch of the Armenian-occupied sovereign territories" (Piriyev, Heydər). Therefore, during the war, Azerbaijan's destruction of missile systems on the territory of Armenia by means of drones was, in fact, an element of the concept of "intra-war deterrence". The goal was to prevent the tension from escalating to the next level. In general, the Second Karabakh War showed that "intra-war deterrence" and strategic weapons systems related to this concept would dominate the battlefield in the coming years.

4. Drones play an important role in detecting and destroying small and medium-range missile defense systems. Armenian Defense Ministry spokesman Artsrun Hovhannisyan, who was best known for denying the successful activities of the Azerbaijani Army in the 44-day war, described Azerbaijan's drone strategy and strength as follows: "This is the fifth-generation war. We estimate that on the first day of the war, in the southern and northern directions of the front there were about 1,000 drones in the air at the same time. Their goal was to destroy air defense systems and firing positions in Karabakh. This goal has been partially achieved" (Mgdesyan, Arshaluys). In fact, if this was what Artsrun Hovhannisyan acknowledged, then it means that the goal was fully achieved. Because the course of events during the war showed that the Azerbaijani Army wreaked several times more destruction on the enemy than they acknowledged. The Bayraktar TB-2, which proved its effectiveness on the battlefield in Syria and Libya against the Russianmade short and medium-range Pantsir systems, was also successfully used by the Azerbaijani Army in the fight against Armenia's missile defense systems (Kasapoglu, Can). It should be noted that only in the first two weeks of the war, the Armed Forces of the Republic of Azerbaijan destroyed 60 missile defense systems (mainly 9K33 OSA and 9K35 Strela) belonging to the Armenian Army. Azerbaijan, which has considerably diversified with regard to its weaponry, used Israeli-made UAVs successfully. In terms of destroying enemy's weapons depots, the Harop - a loitering munition was at the forefront of these UAVs. In particular, these drones were successfully used in the destruction of S-300 missile systems. Thus, Azerbaijan, which was able to diversify its arms trade, reduced its dependence on the Russian arms industry, which has become a tradition in many former Soviet countries. Some sources even claim that $60 \%$ of Azerbaijan's arms imports come from Israel (Piriyev, Heydər). The Bayraktar TB-2, a product of the Turkish defense industry, had an undeniable role in deciding the fate of the war in favor of Azerbaijan. German military expert Ulrike Franke said: "The Second Karabakh War between Armenia and Azerbaijan is the first war won by drones. Armenia used traditional artillery in the battle. Azerbaijan, on the other hand, made a breakthrough by using drones against them. Of course, Armenia did not expect this. Imagine you are assembling artillery and suddenly a drone appears above your head as you prepare to attack. One shot destroys all equipment and personnel" (Kofman, Michael, December 21, 2020). Russian arms manufacturers and military experts claimed that their air defense systems were quite effective in the fight against Turkish UAVs. Thus, the Russian Air Defense units had been conducting anti-UAV exercises of various scale for the past two years. For example, a few months before the war, as a result of joint Russian-Armenian measures against UAVs, it was announced that the Armenian army "should not be afraid of the Turkish TB-2". However, the video materials provided by the Ministry of Defense of the Republic of Azerbaijan showed the weakness of the Armenian army in the face of the TB-2 UAVs. In this regard, Zachary Kallenborn said: "Many factors contributed to Azerbaijan's success in the war, but the use of drones is the most important of them. Azerbaijan used Harop and Orbiter-1K drones and Bayraktar TB-2 UAVs in battles. TB-2 played a special role in 
inflicting heavy losses on the Armenian Armed Forces" (Kallenborn, Zachary). It should be noted that on the eve of the liberation of Shusha, the Azerbaijani Army had reduced the use of UAVs. Taking advantage of this opportunity, Armenian military hinted that they had some kind of "military secret," which would allow them to prevent the use of drones, even though nothing had been said about the nature of this "secret" officially. The first impression of the population was that Russia probably gave Armenia a technology against Azerbaijani UAVs. The Armenians claimed that through this technology they prevented Azerbaijan from using UAVs. However, later it became clear that the reason for the low intensity use of UAVs by the Azerbaijani Army was not Armenia's "secret" technology, but simply foggy and cloudy weather (Kuznets, Dmitry). Thus, if Azerbaijan's weaponry consisted only of Russian weapon systems and equipment, it would not be possible to win the war in this period.

5. Despite the age of technology, traditional tactics and weapons have not lost their relevance. Although the technological superiority of the Azerbaijani Army and the successful use of drones played an indispensable role in the victory, the units used traditional tactics and weapons to clear the liberated lands. The Armed Forces of the Republic of Azerbaijan liberated critical positions, took full control of the border with Iran and began to move towards the Lachin corridor, which is of special strategic importance. The Azerbaijani soldier, who skillfully used traditional tactics and weapons, was able to surprise the experts worldwide. Military expert Michael Kofman says: "There was considerable lag between the degradation of Armenian forces and Azerbaijani territorial advances, but momentum quickly shifted two weeks into the conflict. Early on, Azerbaijan appeared unable to translate tactical success into significant gains, which explains in part the surprise (including my own) at how quickly they were able to put Armenian forces into a precarious and untenable position a few weeks into the war" (Kofman, Michael, October 24, 2020). In fact, Kofman's point was related to the fortifications built by the Armenian armed forces for nearly 30 years and the minefields in the occupied territories. Because a lot of energy and resources were spent on breaching these barriers. According to Alexander Iskandaryan, a political scientist and the Director of the Yerevan-based Caucasus Institute, the successful attack of the Azerbaijan Army from the south had already determined the fate of the war (Iskandaryan, Alexander, October 24, 2020).

\section{Despite the drone age, military-} geostrategic calculus still matters (Kasapoglu, Can). Despite the fact that the South Caucasus occupies a very small place on the world map, the interest in it is much greater than the geographical size of the region. In this regard, it is very important that not only the parties to the conflict, but also a number of foreign powers should demonstrate a constructive position in resolving the conflicts in the region. While paying special attention to the professionalism of the Azerbaijani Army, President Ilham Aliyev also took very serious strategic steps to increase Azerbaijan's prestige in the international arena. Undoubtedly, the national interests of Azerbaijan stood behind these steps. As Mr. President Ilham Aliyev noted in an interview on February 12, 2019: "Sometimes our foreign policy is described as a balanced policy, but I think that our policy is based on national interests" (Piriyev, Heydər). In this regard, the stance of the regional powers in the 44-day war was very important. The neutrality of a number of countries supplying large quantities of weapons to Armenia in political statements is a success of Azerbaijani diplomacy too. Historical examples show that international power centers can take a different approach to conflicts of the same nature. An example of this is Kosovo. The fact that the Republic of Armenia itself had not dared to recognize the so-called "independence" of Nagorno-Karabakh was also the result of the successful policy pursued by Ilham Aliyev. It should be noted that Saakashvili, who had the direct support of a global power such as the United States, failed to achieve this. Georgia, backed by one superpower, was defeated in a war against another superpower. The attitude demonstrated by the Russian leadership since the beginning of the war was a direct success of Ilham Aliyev's diplomacy. Thus, President Ilham Aliyev, who neutralized the forces that Armenia expected 
direct support from in the Second Karabakh War, shortened the duration of the war by achieving the goals set at the outset. This proves the perfection of the military-political strategy in the war.

7. The Special Forces of Azerbaijan were able to engrave their names in the world's military history by carrying out operations that were considered impossible. Analyzing the images of the fighting spread on social media, Can Kasapoglu said that Azerbaijan had also learned from the tactics used by the US coalition against the Taliban in the mountains of Afghanistan since the end of 2001. In those operations, thousands of NATO troops were not present at the same time, typical of the wars of the twentieth century. Within Afghanistan and along the 3,300-kilometer border with Pakistan, US special forces were sent to the areas controlled by Taliban in small groups to carry out "find and destroy" missions. As soon as Armenia's line of defense was beached in the south-eastern part of Nagorno-Karabakh, Azerbaijani Special Forces seized the heights around towns and villages, cut off roads to cities and forced the enemy to flee (Azorbaycanı qələьəуə). A political scientist from Kazakhstan Askhat Kasengali praised the exceptional role of Azerbaijani Special Forces in the Second Karabakh War: "The role of Special Forces in the liberation of Karabakh should be emphasized. Special forces had become a nightmare for the Armenian soldiers. Their high level of training and special tactics allowed them to repeatedly strike at enemy" (The political scientist). Touching upon the training process of Special Forces, the political scientist said that, only four or five out of 100 people in Azerbaijan successfully complete the special forces course, Special Forces do not differ only in physical characteristics, but also know several languages (Azərbaycanı qələbəyə).

Undoubtedly, despite the above-mentioned advantages of the Armed Forces of the Republic of Azerbaijan, the political and military leadership of Armenia try to justify the defeat of the Armenian army with absurd ideas. The Armenian government and lobby want to create the impression in the society that their army "fought" not against the Azerbaijani Army, but against the Azerbaijani-Turkish-Pakistani Army, however during the war they could not provide any conclusive fact. Some Armenian researchers even claim that Russia was interested in their defeat. For example, former OSCE Representative on the South Caucasus Richard Giragosian noted that the "democratic government" in Armenia was considered a threat to Putin's government in Russia. In addition, the researcher expressed concern about the long-term presence of Russian troops in Armenia (Experts on the situation). Consequently, the successful foreign and domestic political course of Azerbaijan had led to the liberation of the occupied territories of Azerbaijan and the strengthening of its geostrategic position.

According to the analysis of Russian military experts, Alexander Stronell proposes the following lessons from the experience of Azerbaijan in the Second Karabakh War (Stronell, Alexander):

The quality of troops on the battlefield is still very important. Thus, $30 \%$ of the martyred servicemen in Azerbaijan were between the ages of 25-27 and had at least 3-5 years of experience. This means that more professional soldiers with combat experience were preferred in the Azerbaijani Army. On the contrary, Armenia's defense consisted of seniors and teenagers. Young conscripts and volunteers were commanded by older, Soviet-trained officers, especially those with no knowledge of modern warfare. As a result, no matter how much technology has changed the battlefield, a skilled soldier is still a key factor in determining the outcome of modern wars;

The character of the battlefield has completely changed. The Second Karabakh War, reflecting Soviet and modern approaches, showed that the war tactics that took place against the backdrop of the US-USSR confrontation had lost their relevance. With financial support from abroad, the Armenian army hoped to maintain its position thanks to the fortifications it had built since the First Karabakh War. However, as a result of air and artillery strikes by the Azerbaijani Army, the defensive positions and air defense systems of the Armenian armed forces were completely destroyed;

National "will to fight" counts - a lot. The unanimous position of the Azerbaijani people to change the 30-year status quo surprised the whole 
world. There was a serious contradiction between the will of the Azerbaijani people and the "determination" of the Armenian leadership. Yerevan was reluctant to send troops to the front, on the contrary, the Azerbaijani people wanted to go to war. Therefore, this war was a national disaster for Armenia;

Self-criticism is a very important issue. Many sources show that Armenians have been repeating the same mistake since 1994, believing in their propaganda. If one side (i.e. Azerbaijan) had been preparing for war, the other side had been, in fact, preparing for the parade. Paul Iddon notes that in early 2020, Armenian soldiers thought that if the war was inevitable, it would be in the form of a war they won in 1994 (Paul Iddon). Relying on Russianmade weapons and equipment, they hoped to perform better in the war, at least to defend the line of defense.

According to Eric Chan, a specialist in Chinese/Korean political and security affairs, due to the combination of modern and old systems with innovative methods, Azerbaijan destroyed Armenia's strong fortifications. The researcher noted that the Taiwanese army should learn three main lessons from the Second Karabakh War (Chan, Eric):

Play the game of drones. The expert notes that Azerbaijan has demonstrated the strongest elements of aviation by mass application of cheap UAVs. Thus, using suicide drones, medium-range guided missiles and artillery, reconnaissance
UAVs, the Azerbaijani Army dealt a devastating blow to the enemy;

Unleash the decoy ducks. Like many other experts, stressing that, Azerbaijani Army successfully used AN-2 aircraft to locate enemy missile systems, the researcher suggests developing mass and cheap "decoys" for the Taiwanese army or using old planes from Taiwan Air Force inventory for this purpose;

Don't fight like they expect you to fight. The expert claims that this approach applied by the Azerbaijani Army resulted in a disaster for Armenia. Like Alexander Stronell, Eric Chan argues that the personnel of the Armenian army were trained by veterans of the 1994 war with wooden guns to execute trench defense. These forces were then correspondingly demoralized by a way of war that had nothing to do with the old Soviet firepower-attrition method that gave Armenia the victory in 1994. Armenian soldiers were destroyed not only physically but also psychologically on the battlefield.

Taking advantage of the war experience of the Azerbaijani Army, even various developed countries consider innovations in their defense industry strategies. Based on recent government reports, former Member of Parliament of UK Richard Ottaway stated: “After Azerbaijan's very successful use of TB-2 UAVs in the war, the UK Ministry of Defense intends to expand its drone program" (Ottaway, Richard).

\section{Conclusions}

The analysis of the Second Karabakh War shows that Azerbaijan conducted the war of new generation and engraved its name in the world's military history. A variety of countries, either developed or developing contemplate the military lessons taken from this war in order to groom their armies for future wars. This fact underscores the significance of Azerbaijan as a player not only at a regional, but international level. Therefore, Azerbaijan as a winner of the war may share its experience with the countries, which want to eradicate their problems of the same nature with "Nagorno-Karabakh conflict".

\section{References}

Abbasova, Arzu, Game of drones in the South Caucasus. Baku: Topchubashov Center, 2020.

Chan, Eric, "What Taiwan's Military Can Learn From the Armenia-Azerbaijan War". December 09, 2020. https://bit.ly/2Orkyov.
Mike, Eckel, "Drone Wars: In Nagorno-Karabakh the future of warfare is now - analysis". October 10, 2020. Available from: https://wapo.st/3qFbMk3.

Foy, Henry, "Drones and missiles tilt war with 
Armenia in Azerbaijan's favour". October 28, $2020 . \quad$ Available from: https://on.ft.com/39SRFbl.

Gustav, Gressel, "Military lessons from NagornoKarabakh: Reason for Europe to worry". November 24, 2020. Available from: https://bit.ly/3d4PrZU.

Paul, Iddon, "The Last Azerbaijan-Armenia War Changed How Small Nations Fight Modern Battles". March 25, 2021. Available from: https://bit.ly/3cUaspz.

Iskandaryan, Alexander, The Second Karabakh War, or the first postpost - soviet war (Vienna: Caucasus Institute, 2020).

Jintcharadze, Mariami, "Nagorno-Karabakh Ceasefire Agreement: Implications for Caucasus Region". December 11, 2020. Available from: https://bit.ly/2MHG7jj.

Kallenborn, Zachary, "Drones are proving to have a destabilizing effect, which is why counterdrone systems should be a key part of us military aid to partners". December 9, 2020. Available from: https://bit.ly/3lqYqXo.

Kasapoglu, Can, "ANALYSIS - Five key military takeaways from Azerbaijani-Armenian war". October 30, 2020. Available from: https://bit.ly/360lHcc.

Kofman, Michael, "A Look at the Military Lessons of the Nagorno-Karabakh Conflict". December 21, 2020. Available from: https://bit.ly/3rKzegw.

Kofman, Michael, “Perspectives. Armenia's military position in Nagorno-Karabakh grows precarious". October 24, 2020. Available from: https://bit.ly/392kp24.

Kuznets, Dmitry, "The battle for Shusha Fighting in Nagorno-Karabakh has reached a turning point. Here are the most recent developments in the conflict zone". November 7, 2020. Available from: https://bit.ly/3p5iYF2.
Mgdesyan, Arshaluys, "UAVs a Gamechanger in Karabakh". October 30, 2020. Available from: https://bit.ly/3qSMteH.

Morgan, Jared, "Armor attrition in NagornoKarabakh battle not a sign US should give up on tanks, experts say". September 30, 2020. Available from: https://bit.ly/3bYgmG7.

Ottaway, Richard, "UK 'must learn lessons' of the Nagorno-Karabakh conflict". January 142021. Available from: https://bit.ly/3sFYBRX.

Stronell, Alexander, "Learning the lessons of Nagorno-Karabakh the Russian way". March 10, 2021. Available from: https://bit.ly/3m3LpmV.

Urcosta, Ridvan, "Drones in the NagornoKarabakh". October 23 2020. Available from: https://bit.ly/3611mnb.

"Azərbaycanı qələbəyə aparmış 3 faktor тәHLіL". 16-11-2020. Available from: https://bit.ly/3d477EE.

Piriyev, Heydər, Rəşad Tahirov, Xəyal İskəndərov, "44-günlük Vətən Müharibəsi. Hərbi-siyasi təhlil", Milli tahlükasizlik va harbi elmlar, No. 1 (2021): 7-14.

Aksenov, Pavel, "Why did Azerbaijan win the war in Karabakh? Military experts answer ". November 11, 2020. Available from: https://bbc.in/39h5BwP.

"Experts on the situation in Karabakh: a world with far-reaching consequences". November 21, 2020. Available from: https://bit.ly/3qUsZ9u.

"The political scientist spoke about the role of Azerbaijan's special forces in the return of Karabakh (VIDEO)". December 21, 2020. Available from: https://bit.ly/2NcOGmt.

Foy, Henry "Drones and missiles tilt war with Armenia in Azerbaijan's favour". October 28, 2020. Available from: https://on.ft.com/39SRFbl. 